\title{
Revitalization of the Narrow-Gauge Zuławy Commuter Railway and its effect on shipping conditions in the Vistula delta
}

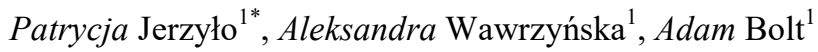 \\ ${ }^{1}$ Gdańsk University of Technology, Faculty of Civil and Environmental Engineering, Poland
}

\begin{abstract}
The article presents the Żuławy Access Railway and the effect of its revitalization on the change of navigational conditions in the Vistula delta. One of the problems analyzed in the article is the intersection of two different transport branches - the inland waterway and rail transport branches. A solution to the problem of their functioning is presented, without any major restrictions. Possible changes in navigational conditions have been described on Martwa Wisła and Przekop Wisły after revitalization of a narrow-gauge railway. The aim of the work is to indicate the optimal solution, taking into account the needs, benefits and possible limitations, and the method of their leveling. The current conditions prevailing in the Vistula delta have been described, obstacles and navigational difficulties, as well as the intensity of unit traffic have been characterized.
\end{abstract}

\section{Introduction}

The left-bank Railroad is an already non-existing narrow-gauge railway $(750 \mathrm{~mm})$, which operated in the county of Gdańsk and Gdańsk. Also known as the Gdańsk Commuter Railway.

Economic issues contributed to the building a narrow-gauge railway $(750 \mathrm{~mm})$ instead of a standard gauge $(1435 \mathrm{~mm})$, this solution is much cheaper than the normal spacing and the construction does not cause as much difficulty as in the normal gauge of rails. Narrow tracks allow the use of harsher horizontal arches and vertical, and it is easier to embed them without much interference in the surrounding landscape [5].

The narrow-gauge railway in Żuławy and the surrounding area is a great tourist attraction. A small fragment on the right side of the Vistula River can provide an unforgettable experience; viewing the sea and the comfort of traveling without traffic jams between the seaside towns. The connection of these modes of transport can be extremely interesting for tourists. Poland, in terms of nature, has very good conditions for using inland transport. Inland shipping, though heavily neglected in Poland, is slowly beginning to once again develop. A dense network of rivers and lakes is conducive to the development of inland transport, however, such good conditions are used to a small extent. The advantage

\footnotetext{
* Corresponding author: patjerzy1@pg.edu.pl
} 
of inland waterway transport is its low cost of transport, as well as low environmental impact, which in today's world is one of the most important issues. The principle of sustainable development assumes such activities as maintaining social, economic and environmental balance [3].

Today, transport around the world should be the cheapest means of transport, as it gives many tourist opportunities, allows you to carry large amounts of various types of goods, is environmentally friendly and emits little noise. In addition, the water transport infrastructure and rolling stock is characterized by high durability and is a transport characterized by a low number of collisions. In non-normative transport it is often the only possible way of moving goods [3].

\section{Narrow-Gauge Żuławy Commuter Railway}

The creation of the first narrow-gauge railways is associated with the development of sugar factories in the area of Żuławy. Demand for sugar beets and the problem of transporting them through boggy terrain often located below sea level influenced the construction of a narrow-gauge railway.

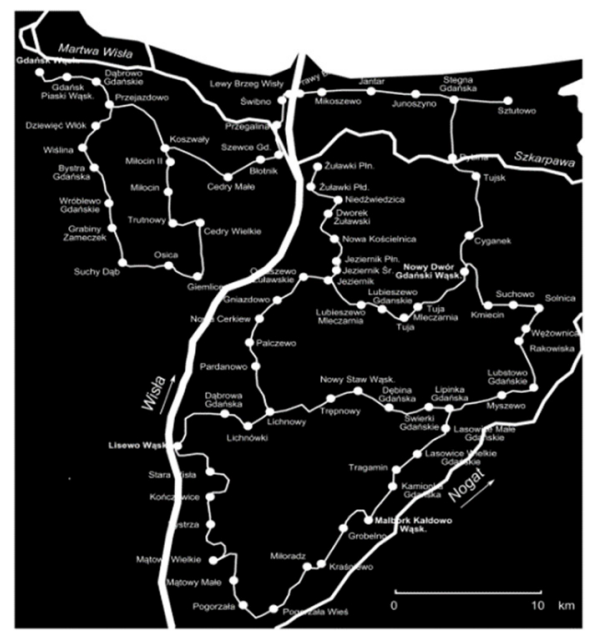

Fig. 1. Network of narrow-gauge queues managed by the company ADKG.

The company Allgemeine Deutsche Kleinbahn- Gesellschaft, abbreviated ADKG, was established in Berlin, noting the benefits of the development of the narrow-gauge railway not only in the transport of sugar beet, but also passenger transport. It took over existing narrow-gauge lines in Żuławy and gradually implemented a plan for the expansion of subsequent lines in the districts of Żuławy Gdańskie, Malbork, Elbląg and Sztum [4].

In 1905, a narrow-gauge railway connected Gdansk and Mikoszewo, this was possible by using a ferry crossing through Przekop Wisły, between Świbno and Mikoszew. The ferry was called Aeigr (in the mythology of the Norse Ruler of the Seas). Modern rotary bridges were built on the Szkarpawa (functioning to this day) and on the Tuga (nonexistent). In addition to the regular lines (Fig. 1), there were branched siding networks that allowed access to almost every village or larger farm.

Owners and governing bodies have changed. Just prior to World War II, this network had a total of almost 336 kilometers of lines, had 96 bridges and culverts, and many workshop; the main one located in Nowy Dwór Gdański and auxiliary ones located in Gdańsk, Malbork and Lisewo. The network serviced 31 rolling stock locomotives and 1063 
railcars (including 40 passenger cars, 12 baggage and 1011 freight). The narrow-gauge railway management institutions employed 222 employees [4, 5].

After the Second World War, the Nazis, fleeing from Żuławy, flooded the area, 2/3 of the narrow-gauge railway line was under water, the stations, workshops, engine rooms and nearly the entire rolling stock servicing the train were destroyed. 25 railway bridges were destroyed. The board of the Gdańsk Narrow-Gauge Railway tried to save and rebuild the network of lines. In 1947, sections of the line on the left bank of the Vistula were opened. The revitalization of the line was effective, in 1948 the length of the active lines was 197 $\mathrm{km}$, and then in $1951-295 \mathrm{~km}$ [5].

Maintenance of the narrow-gauge railway infrastructure has become unprofitable. The authorities have stopped financing the further development of the lines and have not covered the costs of its operation. The infrastructure deteriorated year by year, and in 1955, due to the poor technical condition of the Aegir ferry, the railway crossing through Przekop Wisły was liquidated. At the end of the 1960's the final liquidation of the railway in Żuławy began. On September 8, 1996, the last active coastal line on the right bank of the Vistula was stopped. A part of the infrastructure (e.g. a train turntable) was cut into scrap, the rest was self-destructed or stolen, the rolling stock was almost entirely transferred to other narrow-gauge railway lines. In 1999, the Gdańsk Commuter Rail officially ceased to exist.

In 2000, the authorities of the cities and communities of Nowy Dwór Gdański, Stegny and Sztutowo, under the initiative of the Pomeranian Association of Railway Lovers, decided to undertake the revitalization of the narrow-gauge railway in the coastal belt and to Nowy Dwór Gdański. The lines received a new name - Żuławska Kolej Dojazdowa. The reconstruction of the Mikoszewo - Stegna - Sztutowo and Stegna - Nowy Dwór Gdański lines, was received with great interest, the train operates only during the summer as a tourist attraction.

\section{Inland waterway shipping in the Vistula delta}

Near the city of Gniew, in the village of Piekielko, the Vistula delta starts, two main arms form it: the western arm - Leniwka (former name of the left arm, after regulatory works and excavation of the Vistula Przekop became the main course of the river) and the eastern Nogat arm (separated from the mainstream of the river) with a sluice in Biała Góra, it flows into the Vistula Lagoon near Elbląg). The waters of the Vistula River, as a result of the of making a cross-cut near Świbno, were directed directly to the sea, cutting the left outflow of the sluice in Przegalina (creating the Martwa Wisła) and the Gdańsk Gutter head (right outflow (Szkarpawa River)). This river is quite poor in water, low water level and high water level fluctuations make sailing impossible [9].

The state of the water is from 2.6 meters near the village of Biała Góra, above 3 meters near Torun or even 5 meters from the lock at Gdańska Głowa up to the estuary of the Vistula riverbed (in German called Weichseldurchstich). Przekop Wisły is an artificial outlet with a length of $7.1 \mathrm{~km}$ and a width of 250 to 400 meters. The initiative to carry out the project was frequent flooding and floods in Żuławy and the city of Gdańsk. The flood in 1888 did not give Prussia the power to leave, it had to be done by Mr. Alsen and Mr. Fahl. Work on the Przekop began in the spring three years after the flood. The newly excavated dig for three years had a length of 7,100 meters with a width of 250 to 400 meters. The Opening of the Przekop took place in 1895 by the West German President Gustav von Gossler. Thanks to this investment, the run of the Vistula has dropped by 10 kilometers, which means that the flood risk has decreased. The former course of the Vistula was cut with the locks of Przegalina and Gdańsk Head. An artificial Przekop created Sobieszewska Island and cut off the area of Gdańsk and nearby towns, including the municipality of 
Stegna, therefore, it was necessary to launch a ferry and the narrow-gauge railway ferry route Świbno - Mikoszewo.

Martwa Wisła is the historic main estuary branch of the Vistula (other estates: Nogat, Szkarpawa, Przekop Wisły, Wisła Śmiała). In 1895 it was cut off from the current after the appearance of the Przekop Wisły and after the construction of locks in Przegalina and in Pleniewo. The lock in Pleniewo was dismantled after World War II. Martwa Wisła allows you to get to Gdańsk from the side of the Vistula without the need to enter the sea waters of the Gulf of Gdansk. Martwa Wisła starts in Przegalina with a sluice, flows through the villages of Wiślinka, Sobieszewo, Górki Wschodnie, flows into the City of Gdańsk and flows into the Gdańsk bay. The waters of the Martwa Wisła are the so-called internal sea waters, the entire length of the river is $27 \mathrm{~km}$. The Vistula River is divided into two parts due to its hydrological and morphological character. The first eastern part starting from the Przegalina lock, up to Wisła Śmiała, is a lightly built, natural and quite wide river. This part has an area of about $9 \mathrm{~km}^{2}$, and the depth of the bottom of the section is very diverse, its average is $4.7 \mathrm{~m}$. The second western part starting from Wisła Smiała and ending in the port area in Nowy Port, is dotted with numerous canals, port basins, built-up banks or wharves. Almost all of this part is a waterway for port purposes, the depths in this part are much larger, up to $12 \mathrm{~m}$. The width of the river ranges from 100 to $400 \mathrm{~m}$. The river Martwa Wisła meets the parameters for road class $\mathrm{Vb}$, limited by the width of the sluice to $11.90 \mathrm{~m}$.

\section{Revitalization of the narrow-gauge railway at the river stretch Mikoszewo-Gdańsk}

The concept of revitalization refers to the restoration of what was, i.e. the restoration of the narrow-gauge railway line on the Mikoszewo-Gdańsk section. In the article, the most important element is to check how its reconstruction would affect the shipping conditions on Martwa Wisła and Przekop Wisły. In the case of Martwa Wisła, the kind of bridge that would be the most advantageous should be examined, then finding a convenient location and considering what the crossing would look like. In the case of Przekop Wisły in which the use of the bridge would be quite difficult to implement and would be very costly to consider the use of s ferry, choose the right ferry, explore the frequency and choose the appropriate location.

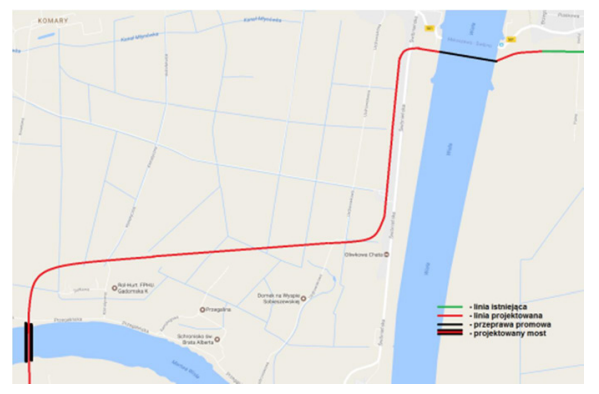

Fig. 2. The plan of crossings for the lines over Martwa Wisła and Przekop Wisły [Own study based on the map - https://www.google.pl/maps/ Accessed: 01-March-2018].

The revitalization of the narrow-gauge railway line would not differ significantly from the original route existing before 1955 (Fig. 2). The ferry crossing would be located not far south of the existing Swibno-Mikoszewo road crossing, crossing the Vistula towards Gdańsk, the line would turn south along Świbnieńska street, then turn to the west avoiding the buildings (here the route was changed, originally leading further south and crossed the 
Martwa Wisła with a bridge over the Przegalina lock) and then heading back south towards the Martwa Wisła where a special bridge for a narrow-gauge railway would be built. It will be invariably the same as in the past and would run through the following towns: Błotnik, Cedry Małe, Koszwały, Przejazdowo, finishing up in Gdańsk.

\subsection{Przekop Wisły - ferry crossing}

The ferry would function like a narrow-gauge railway in the summer and spring. With the maximum number of trips up to 12 with the highest frequency in the afternoon. The above trips do not include the so-called special trips; the narrow-gauge railway organizes such journeys for special circumstances or on request with an individual timetable.

The first option - a railway ferry, which would transport the entire fleet with passengers. Just like the road ferry would be linear, it would flow along a steel rope located between the banks. The line would be stretched only for the needs of the crossing, as it happens during a road crossing. A big help for the existing ferry service is a notification system for upcoming units (ferry lines must then be lowered), larger units indicate their arrival with an acoustic signal, while the smaller whistle, and how is the most respected radio contact with the ship's shuttle service possible. The same notification system can be used in a railway ferry. The use of the first variant would involve the purchase of a specialized ferry or the adaptation of an existing unit for transporting a narrow-gauge railway and adapting the wharf infrastructure (a special ramp) to the entry and exit of the line from the ferry.

In the second option, it assumes the use of an existing road ferry. Passengers using the line would change from a bus stop located near the ferry to the ferry, there would be a second warehouse after crossing and the journey would be continued in other wagons. These solutions seem cheaper and easier, because it does not involve buying a new ferry and the adaptation of the waterfront, but it would involved the purchase of new rolling stock, which would run on the left side of the Vistula River, the construction of the depot, the employment of new staff, the possibility of the formation of lines of a passengers-only ferry service.

To choose the variant of the method of the combination of advantages and disadvantages.

Table 1. Putting together the advantages and disadvantages of variants of a ferry crossing.

\begin{tabular}{|c|c|c|c|}
\hline \multicolumn{2}{|c|}{ Advantages } & \multicolumn{2}{c|}{ Disadvantages } \\
\hline I variant & II variant & I variant & II variant \\
\hline $\begin{array}{c}\text { lack of changes } \\
\text { comfort of the } \\
\text { travel) }\end{array}$ & $\begin{array}{c}\text { Lack of necessity of } \\
\text { the purchase of the } \\
\text { ferry }\end{array}$ & $\begin{array}{c}\text { the purchase and } \\
\text { adaptation of a ferry } \\
\text { train }\end{array}$ & $\begin{array}{c}\text { queues of passengers } \\
\text { using the only ferry } \\
\text { service }\end{array}$ \\
\hline $\begin{array}{c}\text { possibility of } \\
\text { getting a possible } \\
\text { railway track }\end{array}$ & $\begin{array}{c}\text { using the existing } \\
\text { infrastructure of a } \\
\text { quay }\end{array}$ & $\begin{array}{c}\text { employing the staff } \\
\text { for service of the } \\
\text { ferry }\end{array}$ & $\begin{array}{c}\text { need to transfer } \\
\text { (smaller comfort of the } \\
\text { travel) }\end{array}$ \\
\hline $\begin{array}{c}\text { possibility of } \\
\text { getting means of } \\
\text { transportion }\end{array}$ & - & $\begin{array}{c}\text { adapting the ferry } \\
\text { quay }\end{array}$ & $\begin{array}{c}\text { building of new points } \\
\text { of the service of means } \\
\text { of transportation }\end{array}$ \\
\hline tourist attraction & - & - & $\begin{array}{c}\text { purchase of new means } \\
\text { of transportation }\end{array}$ \\
\hline independent ferry & - & - & $\begin{array}{c}\text { employing staff } \\
\text { lack of ability of } \\
\text { getting means of } \\
\text { transportation }\end{array}$ \\
\hline
\end{tabular}


From the data presented in Table 1, it can be concluded that option II from the economic point of view is not profitable, it must also be taken into account that the line only operates during the summer season, so it would not bring profits throughout the autumn-winter period. The best option is variant I - a railway ferry.

\subsection{Martwa Wisła - bridge crossing}

The bridge located on Martwa Wisła would have to be adapted both for the safe crossing of the cableway and to allow navigation on the river quite heavily. Therefore, the most important parameters that the bridge must meet while maintaining a waterway class of $\mathrm{Vb}$, is the width of the clearance under the bridge, at least 7 meters, and the width of the navigable route at least $40 \mathrm{~m}$.

The width of the Martwa Wisła in the selected location is less than $260 \mathrm{~m}$. The river in the area where the bridge crossing is to be found flows across a flat area, the water level is not much lower than the area around the river. Variants of the bridge: 1st variant - high permanent bridge, 2nd variant - rotary bridge, 3rd variant - low permanent bridge, are existing narrow-gauge railway bridges, they will be analyzed in terms of applying similar parameters to the designed bridge in this article. They will differ in their design, parameters, ease of management and impact on shipping conditions.

The multicriteria method is a mathematical analysis that allows choosing the most beneficial solution among the other options described. The most important condition is the adoption of many evaluation criteria (preferably those that represent different aspects, even contradictory ones) in order to find the best solution.

The multi-criteria method is performed in seven stages:

- The first stage is to identify variants (described in the above subsections):

I variant - a permanent bridge (in Koronowo on the Brda River),

II variant - a swing bridge (in Rybina on the Szkarpawa),

III variant - permanent bridge (in Roskosza over Klukówką).

- The second stage is defining the main objectives, which are the priorities for choosing a specific bridge

- The third step is to determine the value of each of the main objectives.

- The fourth stage is the adoption of partial criteria for individual main goals and their evaluation.

- The fifth stage is the preparation of a tabular list of objectives (Table 2).

Table 2. Tabular putting together purposes and their evaluations.

\begin{tabular}{|c|c|c|c|c|c|c|c|c|}
\hline \multirow{2}{*}{$\begin{array}{l}\text { Number } \\
\text { of the } \\
\text { purpose }\end{array}$} & \multicolumn{4}{|c|}{ Criterion } & \multicolumn{3}{|c|}{$\begin{array}{c}\text { Evaluation of } \\
\text { variants }\end{array}$} & \multirow[t]{2}{*}{$\begin{array}{l}\text { Sought } \\
\text { extreme }\end{array}$} \\
\hline & Nr. & Name & Weight & Unit & W1 & W2 & W3 & \\
\hline \multirow[t]{3}{*}{ c(1) } & $\mathrm{c}(1,1)$ & bridge clearance & 0,4 & [m] & 18 & $<40$ & 2,5 & MAX \\
\hline & $\mathrm{c}(1,2)$ & $\begin{array}{l}\text { width of the } \\
\text { waterway }\end{array}$ & 0,4 & {$[\mathrm{~m}]$} & 40 & 17,2 & 50 & MAX \\
\hline & $\mathrm{c}(1,3)$ & waiting & 0,2 & [min] & 1 & 60 & 40 & MIN \\
\hline \multirow[t]{4}{*}{ c(2) } & $\mathrm{c}(2,1)$ & steep uphill road & 0,25 & $\begin{array}{c}\text { [skala 1- } \\
10]\end{array}$ & 9 & 1 & 1 & MIN \\
\hline & $c(2,2)$ & waiting & 0,25 & [min] & 1 & 1 & 1 & MIN \\
\hline & $c(2,3)$ & safety & 0,3 & $\begin{array}{c}\text { [scale 1- } \\
10]\end{array}$ & 8 & 10 & 10 & MAX \\
\hline & $\mathrm{c}(2,4)$ & atraction & 0,2 & $\begin{array}{c}\text { [scale 1- } \\
10]\end{array}$ & 5 & 9 & 2 & MAX \\
\hline c(3) & $\mathrm{c}(3,1)$ & employing staff & 0,3 & $\begin{array}{c}\text { [scale 1- } \\
10]\end{array}$ & 1 & 2 & 1 & MIN \\
\hline
\end{tabular}




\begin{tabular}{|c|c|l|c|c|c|c|c|c|}
\hline & $\mathrm{c}(3,2)$ & operating cost & 0,35 & $\begin{array}{c}{[\text { scale 1- }} \\
10]\end{array}$ & 5 & 6 & 4 & MIN \\
\cline { 2 - 8 } & $\mathrm{c}(3,3)$ & financial cost & 0,35 & $\begin{array}{c}{[\text { scale 1- }} \\
10]\end{array}$ & 9 & 6 & 5 & MIN \\
\hline
\end{tabular}

- The sixth stage is the normalization of grades (Table 3). For the normalization of individual assessments, the following formulas were used: for the minimized criteria (1) and for the maximized criteria (2).

- for minimized criteria:

$$
n(0(r), k, f(k))=\frac{\min _{r \in R}\{w(o(r), k, f(k))\}}{w(o(r), k, f(k))}
$$

- for maximized criteria:

$$
n(0(r), k, f(k))=\frac{w(o(r), k, f(k))}{\max _{r \in R}\{w(o(r), k, f(k))\}}
$$

\begin{tabular}{|c|c|c|c|c|c|c|}
\hline \multirow{2}{*}{$\begin{array}{l}\text { Number of } \\
\text { the } \\
\text { purpose }\end{array}$} & \multicolumn{3}{|c|}{ Criterion } & \multicolumn{3}{|c|}{ Evaluation of variants } \\
\hline & Nr. & Name & Weight & W1 & W2 & W3 \\
\hline \multirow[t]{3}{*}{ c(1) } & $\mathrm{c}(1,1)$ & bridge clearance & 0,4 & 0,5 & 1 & 0,05 \\
\hline & $\mathrm{c}(1,2)$ & $\begin{array}{l}\text { width of the } \\
\text { waterway }\end{array}$ & 0,4 & 0,8 & 0,4 & 1 \\
\hline & $\mathrm{c}(1,3)$ & waiting & 0,2 & 1 & 0,6 & 0,4 \\
\hline \multirow[t]{4}{*}{ c(2) } & $\mathrm{c}(2,1)$ & steep uphill road & 0,25 & 0,11 & 1 & 1 \\
\hline & $\mathrm{c}(2,2)$ & waiting & 0,25 & 1 & 1 & 1 \\
\hline & $\mathrm{c}(2,3)$ & safety & 0,3 & 0,8 & 1 & 1 \\
\hline & $\mathrm{c}(2,4)$ & atraction & 0,2 & 0,5 & 1 & 0,2 \\
\hline \multirow[t]{3}{*}{ c(3) } & $\mathrm{c}(3,1)$ & employing staff & 0,3 & 1 & 0,5 & 1 \\
\hline & $\mathrm{c}(3,2)$ & operating cost & 0,35 & 0,8 & 0,66 & 1 \\
\hline & $\mathrm{c}(3,3)$ & financial cost & 0,35 & 0,5 & 0,83 & 1 \\
\hline
\end{tabular}

Table 3. Table putting together standardized evaluations.

- The seventh and final stage is the comparison of results (Table 4) and selection of the most favorable variant The standardized variant evaluation is calculated from formula (3).

$$
W(o(r))=\max _{o(r) \in o(r)}\{W(o(r))\}
$$

Table 4. Results of choice of the variant.

\begin{tabular}{|c|l|c|c|c|c|}
\hline \multicolumn{2}{|c|}{ Purpose } & \multicolumn{3}{c|}{ Normalised evaluation of variants } \\
\hline Number & \multicolumn{1}{|c|}{ Name } & Weight & W1 & W2 & W3 \\
\hline $\mathbf{c}(\mathbf{1})$ & navigation & 0,4 & 0,72 & 0,68 & 0,50 \\
\hline $\mathbf{c}(\mathbf{2})$ & $\begin{array}{l}\text { improvement of the } \\
\text { narrow-gauge railway } \\
\text { traffic }\end{array}$ & 0,4 & 0,62 & 1 & 0,84 \\
\hline $\mathbf{c ( 3 )}$ & economic & 0,2 & 0,75 & 0,32 & 1 \\
\hline \multicolumn{2}{|c|}{ ocena ogólem } & 0,68 & 0,74 & 0,73 \\
\hline
\end{tabular}

Analyzing the results of the research carried out using the multicriteria method, the second option was most preferred - the bridge in Rybina on the Szkarpawa River. The variant is optimal for both sailing and narrow-gauge railway. The bridge in Rybina is still 
working today by allowing the railway to cross over Szkarpawa without the need to stop shipping traffic. The most important aspect of the choice of this bridge is to consider whether the span should be still open for the needs of the line or still closed for the needs of navigation.

\section{Summary}

Inland shipping that was neglected in Poland for a certain period has slowly begun to develop again. A dense network of rivers and lakes is conducive to the development of inland transport, however, such good conditions are not yet fully used. The principle of sustainable development assumes such activities to maintain the social, economic and environmental balance so that the next generations can benefit from what is now. It is worth considering the initiative of investing in inland transport in order to bring benefits not only to us, but also to future generations.

The hypothetical revitalization of the narrow-gauge railway on the section of Mikoszewo - Gdańsk, showed a conflict that would take place at the intersection of the two routes at Przekop Wisły and on Martwa Wisła. While finding a solution at Przekop Wisły was not very difficult, a previously used railway ferry was used there, which operated before the Second World War. And it did not hinder the Świbno - Mikoszewo road ferry in the area of Przekop Wisła. The challenge was to choose the bridge on the Martwa Wisła. The bridge would have to be adapted to the travel of lines and not limit shipping conditions. Of the three bridges: permanent and high - where the difference in height for the queue would be too large but the conditions under the bridge would be ideal for navigation, rotational - optimal for the queue and shipping with the only problem waiting for opening / closing, fixed and low - would make it impossible to navigate at this point, through the negligible clearance under the bridge. A rotary bridge was selected using the multicriteria method. The restriction imposed by this bridge for tall vessels is the waiting time for opening the bridge. The bridge would remain permanently open for shipping and would only be closed for the duration of the line.

\section{References}

1. Dz.U.2002.77.695, Rozporządzenia Rady Ministrów z dnia 7 maja 2002 roku w sprawie klasyfikacji śródlądowych dróg wodnych,(2002)

2. P. Jerzyło, Modelowanie strumienia ruchu środków transportu śródladowego $w$ delcie Wisty - analiza dostęnych połaczeń transportowych, TTS Technika Transportu Szynowego. -., nr. 12, s.724-729 (2015)

3. J. Kulczyk, J. Winter, Śródlądowy transport morski, (Wrocław 2003)

4. R. Witkowski, Koleje Wąskotorowe na Żuławach, (Poznań 2009) 22

5. [Online] Available: https://kolejzulawska.pl/. [Accessed: 22-Feb-2018] 29

6. [Online] Available: https://dawnygdansk.pl/. [Accessed: 22-Feb-2018]

7. [Online] Available: http://gwardak.com/. [Accessed: 22-Feb-2018]

8. [Online] Available: http://ptmkz.pl/. [Accessed: 22-Feb-2018]

9. [Online] Available: http://encyklopedia.pwn.pl/, hasło: Wisła, [Accessed: 22-Feb2018]

10. [Online] Available: http://rzgw.gda.pl/. [Accessed: 01-March-2018] 